E3S Web of Conferences 1, 11004 (2013)

DOI: $10.1051 / \mathrm{e} 3 \operatorname{sconf} / 20130111004$

(c) Owned by the authors, published by EDP Sciences, 2013

\title{
Impact of human activities on Aluminum contamination in the drainage canals in the Nile Delta, Egypt
}

\author{
A. A. Alne-na-ei ${ }^{1}$ and M. Authman ${ }^{2}$ \\ ${ }^{1}$ Zoology Department, Faculty of Science, Menufiya University, Shebeen Alkom, Egypt, azalnenaei@yahoo.com \\ ${ }^{2}$ The National Research Centre, Hydrobiology Department, Cairo, Egypt, mnauthman.yahoo.com
}

\begin{abstract}
Aluminum is released into Sabal drainage canal through the emissions of recycled aluminum industries, the discharge of stations of water purification that contain huge amount of aluminum sulfate (alum) and the extensive use of clay in the industry of packed bricks. The aim of this study was to investigate the impact of human activities on $\mathrm{Al}$ accumulation on water and fish consumption. The field and laboratory studies of water samples and different fish tissues (muscles, liver and ovary) revealed that water samples had higher levels of Aluminum if compared to those collected from other localities. Tissue samples of the fish, Tilapia zillii had higher levels of Al which exceeded the international permissible limits. From a public health standpoint, the increased concentrations of Al in water samples and the fish tissues in the are is a matter of concern. Therefore, the research suggests the elimination of illegal aluminum industries and replace the smaller and old stations of sewage treatment by another modern type capable of collecting and treating huge amount of sewage, with high efficiency of treatment and purification.
\end{abstract}

Key words: Aluminum, drainage water, fish, Nile Delta. 